\author{
Dr. Czeglédi László \\ Eszterházy Károly Egyetem, Médiainformatika Intézet \\ czegledi.laszlo@uni-eszterhazy.hu
}

\title{
ADAPTÍV TANULÁSI KÖRNYEZETEK KÖNYVTÁRI TÁMOGATÁSA
}

\section{Bevezetés}

Kétféle környezet metszetét keressük: adaptív tanulási környezetek és könyvtári környezetek. Mindkettő önmagában is meglehetősen bonyolult szerkezet vagy összetétel. Ennek ellenére, ha alaposabban megvizsgáljuk az összetevőket, akkor számos kapcsolódási pontot találunk, közöttük olyanokat is, amelyek egymást kiegészítik, sőt adott esetben kölcsönösen támogatják a szomszéd környezet tevékenységét. Nem mindig egyértelmű azonban belátni azoknak a mindennapjainkban már szinte megszokott tényezőknek a hatását, miszerint az említett két környezet szoros kapcsolatban áll egymással. Ráadásul mára bizonyos pontokon nem nélkülözhetik egymás szolgáltatásait, eszközeit, valamint a humánerőforrás szellemi kapacitásának folyamatos áramlását a két terület között.

Az oktatás könyvtári támogatásának eszközei egyre szélesebb spektrumban jelennek meg, emellett pedig folyamatosan fejlödnek az általuk nyújtott szolgáltatások. Az elektronikus tartalomszolgáltatás az elmúlt évtizedben egyre nagyobb teret nyert, mára pedig szinte a mindennapi életünk részévé vált. Az oktatás könyvtári támogatásának egyik legfontosabb eszköze az elektronikus tartalomszolgáltatás.

Számos olyan fogalom szerepel a vizsgált témakörben, amelyek használata területenként némileg módosulhat, vagy többletértelmezést kaphat attól függően, hogy milyen szövegkörnyezetben használjuk ezeket. Egyet szeretnék kiemelni ezek közül, az adaptivitást, amely alapvetően az alkalmazkodás és fejlődés egységét jelenti. Könyvtári oktatástámogatás, tartalomszolgáltatás oldaláról pedig az adaptivitás jelentheti egyfajta információs konzervek készítését, amelyek tartalma „felbontás” után frissíthető, újratölthető a változó használói igények függvényében. Másrészt pedig jelentheti a mindennapi oktatási igények kielégítésére irányuló folyamatos információ- és tartalomszolgáltatást.

\section{Az adaptív tanulási környezetek könyvtári támogatása, mint rendszer}

Az előzőekben említettek egy olyan komplexet képeznek, amelyet egy adott környezetben szemlélve rendszernek nevezhetünk. Egy rendszernek számos objektuma, követelménye létezik. Nem kívánom sorra venni minden egyes elemét, csak a legfontosabbakat említem az általam tárgyalt két környezet összefüggésében. Egy rendszernek célokkal kell rendelkezni, hiszen ok nélkül nincs értelme müködtetni. Ezeknek a céloknak az elérésére a rendszer különféle eszközöket, metódusokat alkalmaz, az alapvető rendszerelemek pedig a jól ismertek: bemenet, folyamat, kimenet, visszacsatolás.

Hogyan müködnek ezek esetünkben? A két környezet legfontosabb célja, hogy olyan átlátható, demokratikus tanulási tereket hozzon létre, amelyeken belül megvalósulhat a szereplök közötti vertikális kommunikáció. Ez a digitális tanulás feltételei között is megfogalmazódik. (Benedek A., 2013)

Jelen esetben a demokratikus tanulási tér egyik helyszíne a könyvtár. A tanulási tér demokratikus, a tanulás lehetőségei azonban nem feltétlenül minden esetben demokratikusak. A könyvtár megkísérli ezt megteremteni (egyre nagyobb sikerrel). 
A vertikális kommunikáció a demokratikus tanulási terek egyik megjelenési formája. Ennek megvalósulása komoly szervezési feladatok tervezését teszi szükségessé, ugyanakkor hatékony és ésszerü megvalósítására nem mindig találjuk meg a megfelelő eszközöket és a megfelelő rendszert. Ráadásul esetünkben három (sőt négy) szereplő köré kell felépíteni: tanuló, tanár, könyvtáros (fontos szereplők ezeken kívül az informatika hardver-szoftver oldalának résztvevői - mondhatjuk a negyedik dimenzió -, de erre jelen írásban nem térek ki).

Ha folytatjuk a rendszer sémájával kapcsolatos gondolatmenetet (a rendszer célját már megfogalmaztuk), akkor a következő lépés a bemenet. Ennek a kettős rendszernek a bemenete sokoldalú, legfontosabb tartalmi elemei a következők:

- tartalmi információk, dokumentumok, objektumok (analóg és digitális)

- instrukciók (a kétféle rendszer használatához, a tartalmi információk megismeréséhez, és használatához, a tudásanyag bevéséséhez kötődnek)

- feladatok

- támogató szolgáltatások (és ezek alkalmazásához szükséges információk)

- technikai feltételek (intézményi és saját)

- a rendszer szereplőiről szóló kötelező és hasznos információk

- a rendszer müködéséhez szükséges, szervezéshez, vezetéshez, müködtetéshez kapcsolódó információk

A bemenet jellemzői a szereplök oldaláról:

- kognitív funkciók fokozott szerepe

- moderálás (a környezet oldaláról)

- önszabályozás (a szereplők oldaláról)

- technikai képességek (a mindenkori digitális írástudás elvárásainak megfelelően)

A rendszerbe bemenetként betöltött információk, adatok, feladatok stb. általában valamiféle folyamatokat generálnak. Konkrétan azokat a folyamatokat, amelyek elvégzésére, végrehajtására a rendszer elkészült (és felkészült). Ez tulajdonképpen az adaptív tanulási környezet és a könyvtári környezet kettősségének vonatkozásában az oktatási-tanulási folyamat lezajlása, amelynek részletezése most nem feladatunk. Éppígy nem foglalkozom a rendszer kimenetével sem, ami természetesen számos módon jelenhet meg, és nem csak a konkrét feladatok számszerü eredményeiben.

A könyvtári támogatás oldaláról nagyobb jelentőséggel bír a rendszernek a feedback vagy visszacsatolás eleme. Ez jelenti ugyanis a szolgáltató intézmények számára azt a kapaszkodót, amely alapján folyamatosan újratervezheti a támogatás rendszerét, módosíthatja, újraépítheti a tartalomszolgáltatás elméleti szerkezetét. A visszacsatolásnak két okból is minden szereplöt érinteni kell a rendszerben: a rendszer felé történő visszajelzés; a rendszer szereplöi között megvalósuló vertikális kommunikáció.

\section{A repozitórium mint eszköz}

Bizonyos szempontból a repozitórium jellegénél fogva alkalmas lehet a visszacsatolások egy részének kezelésére. Ez abból a jellemzőből fakad, hogy a repozitórium (elsősorban az intézményi repozitórium) lehetőséget teremthet arra, hogy a különböző szintű használók ne csak passzív szereplőként vegyenek részt a tartalom építésében, hanem maguk is aktívan hozzájárulhassanak a repozitóriumok tartalmának alakításához. (Czeglédi L., 2015)

Amennyiben nevesítjük a rendszer fö összetevőit, akkor tulajdonképpen a virtuális tanulási környezet támogatásának a hagyományos és digitális könyvtári szolgáltatások mellett két fó komponense van: a képzésmenedzsment rendszer és az intézményi repozitórium (bár ez utóbbi jó esetben szintén könyvtári keretek között müködik). 
Ma már alapvető feladat bármilyen digitális alapú tartalomszolgáltató rendszer létrehozásánál, müködtetésénél figyelembe venni azt, hogy ne csak statikus rendszerekben gondolkodjunk, hanem dinamikus, az állandóság folyamatos megújítására törekvő szervezeteket hozzunk létre.

\section{Tananyagrepozitórium - oktatási-tanulási forrás}

Írásom témájából adódóan főként a tananyagrepozitóriumok kapcsán szeretnék foglalkozni néhány gondolattal. Az előzőek kapcsán azonnal felmerül a kérdés: Csak egy tárházként vagy digitális szertárként használjuk? A digitális tananyagrepozitórium egyik legfontosabb tulajdonsága, hogy a képzésmenedzsment rendszerekkel együttmüködve lehetőséget ad a hallgatóknak a tanulási források és a tanulás mechanizmusának részben önálló szervezésére és egyfajta navigációs támogatására.

Mindenekelőtt szükséges tisztázni a tananyagrepozitóriumok létrehozásának szerepét, ugyanis ezzel kapcsolatban is találkozhatunk félreértésekkel, illetve rossz gyakorlatokkal. A tananyagrepozitóriumok létrehozása legalább három kérdést vet fel: Milyen céllal hozzuk létre? Mit tartalmaz, vagy mit kellene tartalmaznia? Milyen szolgáltatásokat nyújt?

Célok: tartalomszolgáltatás, újrafelhasználás, verziókövetés, átjárhatóság, rendszerezés, módszertani támogatás, oktatási technológiák támogatása, az oktatás feltételeinek szélesítése, változatossá tétele

Tartalom: Sajnos a tananyagrepozitóriumok jelentős része valóban csak tananyagokat tartalmaz, így kevéssé elégíti ki a célok között megfogalmazott feladatokat. Meg kell tehát vizsgálni, hogy a tananyagelemek valójában milyen tartalmat fednek le.

A kutatási eredmények megjelenésében viszonylag jól elválaszthatók a gyakorlati megoldások, amelyek tulajdonképpen átmenetet is képezhetnek a pre-digital és a post-digital kutatások közzétételének módszerei között. Ezen a területen számos hasonló jellemzőkkel rendelkező dolgokat találhatunk (pre-prints, peer-review, folyóiratok stb.).

Azonban az oktatás területén kevésbé koherens formákkal találkozhatunk. A digitális formában, intézményi összefogásban készített oktatási anyagok általában jegyzetek, képgyüjtemények, animációk, felmérések stb. (rendszerint tankönyvek) (Jones, R., 2006). Lényegesen szélesebb spektrumban mozognak, mint a kutatási eredmények megjelenése. Így sok esetben az a helyzet áll elő, hogy míg egy intézmény a kutatási eredményeit az intézményi repozitóriumban szinte problémamentesen meg tudja jeleníteni, a tananyagelemekkel ez nehezebben müködik.

Nagyon nehéz helyzetek állhatnak elő a tananyagokkal saját szerzők esetében is, ráadásul nem kerülhetők meg a különböző típusú objektumok és fizikai paramétereik okozta problémák, valamint a szerzői jogok (a felhasználás és ezzel kapcsolatban a szerzői jogok tekintetében sok esetben sajnos nem valós, hanem intézményi és/vagy egyéni érdekek döntenek). Természetesen ezek az akadályok az újrafelhasználás és az átjárhatóság követelményeit jelentősen aláássák.

A tananyagelemek rendkivül heterogén összetételüek lehetnek, ami maga után vonja a metaadatokkal, fájlméretekkel kapcsolatos problémákat is. Mindezt egy repozitóriumon belül kezelni nagy kihívást jelent, ugyanakkor az intézményi erőforrások hatékonyabb kihasználására ad lehetőséget. Az intézményi repozitóriumokban még ritkán találkozunk tananyagelemekkel, ezek leginkább külön tananyagrepozitóriumokban jelennek meg. Sajnos itt is elsősorban tankönyvekkel, teljes tananyagokkal találkozhatunk, az egyéb objektumok szerepeltetése még nem jellemző.

A felsőoktatási intézmények repozitóriumai elsősorban a „hagyományos” anyagok gyüjtésére, közzétételére összpontosítanak, mint a diplomamunkák, disszertációk, képek, 
videók, egyéb adathalmazok. Ezek az anyagok nagyon hasznosak, azonban egyre nagyobb az érdeklödés a tananyagelemek újrafelhasználása irányában. Éppen ezért a tárolásukat aprólékosan, részletekre kiterjedően kell megoldani, alkalmazkodva a képzésmenedzsment rendszerek fogadóképességéhez. A hagyományos repozitóriumok ez okból általában nem felelnek meg a tananyagrepozitóriumok igényeinek.

Egy jól és hatékonyan müködő tananyag repozitórium felépítése komplex tervezőcsapatot kíván, amelynek szereplői informatikai szakemberek, oktatók, oktatási szakértők, oktatástervezők, könyvtárosok és véleményem szerint a hallgatók is. (Cervone, H. F., 2012)

A repozitóriumok képzésmenedzsment rendszerekben történő alkalmazása az előzőekben említett jellemzőktől, tervezéstől függ. A digitális tananyagrepozitóriumnak alapvetően két kérdést kell megválaszolni. Az egyik a tartalomra irányul, azaz mit tanitsunk-tanuljunk, a másik pedig a módszerre kérdez rá - hogyan sajátitsuk el az új ismeretek egyes elemeit. Az első kérdésre adott válasz egyszerü, hiszen meg kell határoznunk a tartalom részeit, amelyet tetszőleges szintig finomíthatunk. Tulajdonképpen itt választjuk ki az ismeretek elsajátításához szükséges dokumentumokat, objektumokat. Ezek „lehívása”, indexelése történik a repozitóriumokból.

\section{Tananyagrepozitóriumok, hozzáállás, feltételek}

Mi történik, ha létre akarunk hozni egy elektronikus tananyagrepozitóriumot? Elsősorban az előzőekben megfogalmazottak alapján - lefektetjük a célokat, amelyek többnyire az azonos jellegü digitális tartalmak, a közzététel centralizálása, közös indexelése, ingyenes közreadása, folyamatos bövítése stb. körében fognak megjelenni.

De! Mindezeket figyelembe véve az adaptív rendszerek támogatásánál a cél nem feltétlenül egy könnyen, gyorsan hozzáférhető, digitális tartalmakat szolgáltató digitális könyvtár létrejötte, hanem egy e-learning rendszerrel társitott repozitórium létrehozása és müködtetése. Tehát nem egy digitális könyvtár jön létre, hanem egy olyan rendszer, amely képes alkalmazkodni (adaptív), képes átalakulni (transzformatív) és mindezek mellett folyamatos fejlödésre képes és kreativ.

Ehhez olyan tartalmak létrehozására van szükség, amelyek tárolhatók a különböző repozitóriumok rendszereiben, tehát valóban tananyag repozitóriumként müködnek a fentiekben leírtak szerint. Ugyanakkor rendelkeznek azokkal a tulajdonságokkal, hogy az elearning képzésmenedzsment rendszerekbe interaktiv módon beilleszthetök legyenek (függetlenül a fájlformátum kérdésétől, hiszen a jelenleg leggyakrabban használt fájlformátumok egy része alkalmas bizonyos fokú interaktivitásra).

A két környezet kapcsolatában pedig elemi szinten fontos a fájl- és szoftvermigráció kérdésének felszínen tartása, a tapasztalatok szerint úgy tünik, ez okozza a legtöbb problémát a folyamatok gördülékenységének, színvonalának szinten tartásában.

Néhány dolog, amire oda kell figyelni a tervezésnél - a gyakorlati használatot figyelembe véve (nem fontossági sorrendben):

- az adott tartalmak elavulásának sebessége

- a tartalmakon belüli navigáció ésszerüsége, korszerüsége, hatékonysága

- képernyőképek átláthatósága

- a hyperlinkek használatának egységessége

- csak közvetlen linkek használata

- a fizikai formátumok alapján történő szürés lehetősége, megbízhatósága (ennek alapja, hogy tananyagelemeket tudjon tárolni és szolgáltatni a repozitórium)

- metaadatok rendszerének előzetes, minden szempontra kiterjedő elemzése

- metaadatok rendszerének bövitési, transzformálási lehetösége 
- adatletöltés egyszerüsége

- adathozzáadás -társítás lehetősége

\section{Folyamatos fejlesztés, regenerálás - adaptivitás}

Az adaptív tanulási környezetek problémáinak megoldására például a Moodle CMS rendszer többnyire alkalmas (a képzésmenedzsment rendszerek részéröl). Közel sem annyira azonban, hogy meg tudja válaszolni a tevékenység szintjén az előzőekben megfogalmazott kérdéseket. Szükség lenne egyre több olyan tananyagrepozitóriumra, amelyek akár az elemi egységekig részletezve tárolja a tananyagelemeket, és hatékonyan tud együttmüködni a képzésmenedzsment rendszerekkel. A navigáció legfontosabb feladata pedig, hogy segítse a hallgatót a tanulási fázisok és a hozzájuk rendelt tanulási források közötti eligazodásban.

Véleményem szerint még csak a közepén járunk annak az útnak, ami fokozatosan fedi fel a repozitóriumok oktatásban történő alkalmazásának lehetőségeit. A lehetőségek azonban határtalanok, csak a mi találékonyságunktól függnek.

\section{Irodalomjegyzék}

Benedek András (szerk.) (2013). Digitális pedagógia 2.0. Budapest: Typotex. p. 42-47.

Cervone, H. Frank (2012). Digital learning object repositories. In: OCLC Systems \& services: International digital library perspectives, 28 (1) p. 14. https://doi.org/10.1108/10650751211197031

Czeglédi László (2015). Könyvtár és oktatás. Eger: Líceum. p. 72.

Hasegawa, Shinobu-Kashihara, Akihiro-Toyoda, Jun'ichi (2003). E-learning library with local indexing and adaptive navigation support for Web-based learning. In: Journal of educational multimedia and hypermedia, 12 (1) p. 96-101.

Jones, Richard-Andrew, Theo-MacColl, John (2006). The institutional repository. Oxford: Chandos. p. 12. https://doi.org/10.1533/9781780630830 